\title{
Minority (Serb) Returnees to Croatia: Reintegration or New Immigration?
}

Mesić, Milan; Bagić, Dragan

Source / Izvornik: Ethnic Minorities and Politics in Post-Socialist Southeastern Europe, 2016, 211 - 231

Book chapter / Poglavlje u knjizi

Publication status / Verzija rada: Published version / Objavljena verzija rada (izdavačev PDF)

https://doi.org/10.1017/CBO9781316671290.013

Permanent link / Trajna poveznica: https://urn.nsk.hr/urn:nbn:hr:131:531846

Rights / Prava: In copyright/Zaštićeno autorskim pravom.

Download date / Datum preuzimanja: 2023-04-26

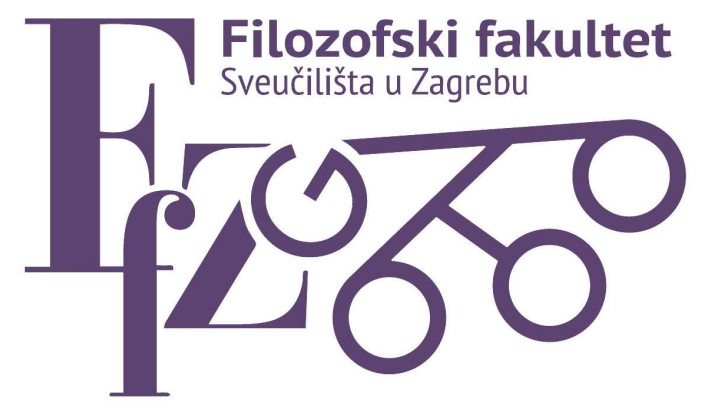

Repository / Repozitorij:

ODRAZ - open repository of the University of Zagreb Faculty of Humanities and Social Sciences
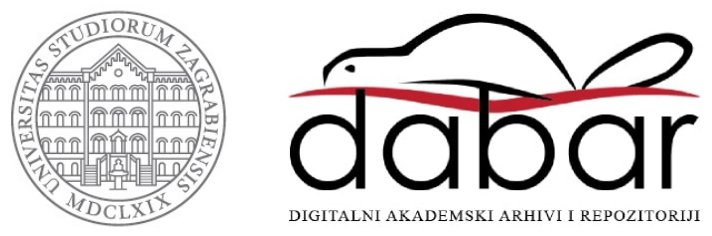


\title{
12 Minority (Serb) Returnees to Croatia Reintegration or New Immigration?
}

\author{
Milan Mesic and Dragan Bagic
}

\section{Traditional Understanding of Refugee Return to Their Homes}

Studying small and (relatively) closed communities, traditional anthropology and ethnology have contributed to conceptualizing an essentialized connection between man and space. From this perspective, human beings, i.e., human groups, feel "naturally" attached to the place (in the territorial sense) of their residence, which primarily refers to the place of birth, their native region, and/or homeland. The notion that people are "beings of place" is often reflected in botanical metaphors, and we say that someone is "rooted" in a place, or "uprooted" when this place is abandoned. ${ }^{2}$

George Gmelch generally defines return migration as "the movement of emigrants back to their homeland to resettle,"3 depicting it thus as the (final) ending to the migration movement. Although it is reasonable to assume that the return of refugees is often significantly different from the return of voluntary emigrants, the advocates of repatriation basically developed a theory that all refugees (normally) favor repatriation, ${ }^{4}$ which they consider the best durable solution to the refugee exodus. ${ }^{5}$ In the international discourse of repatriation, return is depicted within an essentialized concept, according to which refugees return to their "natural" homes ${ }^{6}-$ a concept which is based on an idealized image of pre-war (local) life. If home is the "center of the world," then the loss of home is the "undoing of the meaning of the world."7

In short, refugee return has traditionally been viewed as a single and unique act. Furthermore, it implies a happy ending to the refugee cycle, and as a durable solution, it releases the responsible international organizations from further care for former refugees. While the status of a refugee is associated with negative connotations of a victim - suffering, "uprooting," loss of "home" - or in short social pathology, return is perceived as 
the opposite of it all. It represents something good that is finally happening (again) to the refugees, a kind of "natural" renewal of their original life. The right of displaced persons to return to their "homes of origin," at least regarding this region, received great support from the "international community." If basic prerequisites for the return are acquired, and if it becomes desirable from the standpoint of the international community, the non-return option chosen by the refugees themselves is perceived as "not normal" and their status as "non-returnees" pathological. ${ }^{8}$ This is based on the standpoint that, by returning, refugees lose their refugee label, and become "normal" people who, as everyone else, again belong to their "home" and "homeland." It is only by means of return that the "natural" and "national" order, which is assumed to have existed before the displacement, can be re-established. ${ }^{10}$

In this chapter, we would like to identify key political, economic, socio-demographic, cultural, and other changes in Croatia, which affect the return of Serb refugees to their places of origin. It is relevant both socially and academically to explain the major reasons for a drastic reduction of the ethnic Serb minority in the total population of the country (from 12.2 percent in 1991 to 4.4 percent in 2011). In the social-political sense, reintegration of the Serb returnees has remained one of the critical issues in the democratic constitution of the new Croatian society. As to refugee studies and policies, we call into question some well-established traditional views concerning the "natural" aspirations of refugees to return to their homelands and homes, once their security is guaranteed.

\section{Criticism of the Traditional Understanding of (Minority) Refugee Return}

Unfortunately, it turned out that the "international community" assumed, in a facile way, that most refugees and internally displaced persons would want to return to their pre-war homes (especially in Bosnia-Herzegovina, and then in Croatia and Kosovo). This did not happen, however, because a large number of minority refugees and displaced persons were not willing to return for good to their homes due to radically changed circumstances in their immediate and wider environment, whether for the short term and/or for the medium term. Monitoring of returnees soon "revealed" a worrying trend that many of them, sooner or later, and for different reasons, migrate again. Many requested and returned houses have been sold, replaced, rented, or remained empty. Thus, the vast majority of minority returnees ${ }^{11}$ consist of elderly people who return to peripheral, rural places of origin, where they can rely on a small state pension and agriculture for their 
needs. ${ }^{12}$ Barbara Harrell-Bond ${ }^{13}$ was among the first to question the wish of refugees to return home. Even if they return, for some of them it does not necessarily signify the end of the refugee experience. ${ }^{14}$ In many cases, returning does not improve the living conditions of persons who used to be refugees, and consequently returnees, for various reasons, have to move again.

Therefore, the traditional notion of return, as well as home, has recently been subjected to severe criticism from migration and refugee theorists and researchers. A deeper insight into the motives of refugees would show that some of them, for various reasons (time spent in the refuge, security, economic and political conditions in the country), are not prone to repatriation (particularly if they sought refuge in a developed country, or a country of their ethnic group). They decide to return if they find other durable solutions less feasible. Primarily politicized groups of refugees tend to refuse return as a solution to their refugee status. Indeed, the refugees "may be associated with previous regimes and attached to former ethnic and political elite structures, and thus be subject to hostility and jealousy" once they return ${ }^{15}$.

Recent studies on return (including our own) ${ }^{16}$ show that return does not always ensure a "natural" reincorporation of returnees into the society of origin, but rather that those who return to their homes often find them significantly different, changed, both physically and socially, and that they need to negotiate their re-settlement in a very different context of power and inequality. ${ }^{17}$ Jansen and Löfving ${ }^{18}$ demonstrate that, after violence and destruction, re-emplacement should be viewed in the context of economic and political changes. Such large-scale perturbations intersect with changes in individual and social trajectories. ${ }^{19}$ In other words, the process of return affects all dimensions of life, and is influenced by a wide range of individual, contextual, and psychosocial factors. ${ }^{20}$ This does not mean that returnees cannot be moved by a strong feeling of attachment to their place of origin. However, we would like to point out that the feelings of belonging and attachment to a place (home) should be perceived in connection with broader social and historical processes which provide the basis for people to have demands from a certain place and call it their home. ${ }^{21}$

There was an attempt to explain the slow progress in increasing the number of minority returnees by insufficient security conditions and violation of human and refugee rights. Unfortunately, this was more or less true, but the causes of minority non-return, as shown by more comprehensive analyses, were deeper and broader, including social and economic conditions. Indeed, new patterns of exclusion in the society of origin emerged with new status hierarchies. Each individual is faced with 
making his or her own decision (affecting other family members too), taking into account a mix of reasons. ${ }^{22}$

Recent research has shown that return is ambivalent in the first and subsequent generations of both voluntary and involuntary migrants. Return migration is often not a simple movement and not a final act. Exploring the return of Croatian immigrants of various generations and demographic profiles, Jasna C̆apo $\breve{Z}$ megac ${ }^{23}$ concluded that return migrations can be better understood as a type of immigration, as it seems that there is no justification for the traditional conceptual differentiation between immigration and return. Therefore, return is today conceived in much broader terms - as a stage within a fluid migration cycle of spatial mobility. ${ }^{24}$

It seems that within a short time the understanding of return as a complex, long-term, and multi-directional process prevailed. Experiences of past return operations have shown that, in reality, return and reintegration do not occur as a "natural" act, and they do not take place in continuity and without obstacles, especially in post-conflict situations, but rather represent complex processes prone to changes in line with local circumstances. ${ }^{25}$ In the cases of Croatia and Bosnia-Herzegovina, and actually, more or less in all post-conflict societies, return and reintegration take place in the context of deep changes, including the transition to new economic and political systems. "From a perspective of the returnees, therefore, return and reintegration is a dynamic and contested process which means to negotiate one's position in a new context of power and inequality." 26

Studies have also revealed that the terms "home" and "return to home," on which repatriation endeavors are based, do not always have the same meaning for the refugees, i.e., the returnees themselves. In practice, most (Bosniak) returnees experience return with a basic feeling of ambivalence. On the one hand, they have re-possessed their "small home," on the other hand, their "large home" seems to be forever lost. ${ }^{27}$ Tania Ghanem ${ }^{28}$ noted the paradox of refugee return: "How can it be assumed that refugees are returning 'home' when the very reasons they left were that they did not feel 'at home' anymore?"

In the late 1990 s, the idea that return would provide fulfillment, an ending to a cycle, allowing the refugee to re-establish the pre-exile circumstances of his or her "home," was called into question. Surveys of refugees who went "home" highlighted the complexity of their experiences, marked with economic, psychological, and social difficulties. ${ }^{29}$ One started to re-examine what was previously a basic assumption made by international and other parties interested in the return of involuntary migrants - the assumption that the returnees simply "return home." 
"The reality is much more complex, and is often related to the changed identity of the migrant and the changed context in the home country. Returning to a changed country, where social relations, political structures and economic conditions are not what they used to be, may be equivalent to arriving in a new place." 30

According to this new understanding, "home" is not a physical place but a combination of social relations and cultural meanings. ${ }^{31}$ Moreover, the very concept of "home" is transformed in a war. Returnees are often faced with a "home" which has changed substantially over the time of their absence, and now claim the difficult process of integration into a new society. Rather than simply considering return migration as "going home," it should be viewed as an intrinsically transnational phenomenon, as it takes place across national state borders. ${ }^{32}$ Return can be better conceptualized as an open-ended process, which often takes place over a longer time period and may include phases of dual residency and significant movement between the two residences.

\section{Changed Social Context for Minority Returnees}

In any country, conflicts, especially on ethnic or religious grounds, lead to deep and far-reaching social consequences, particularly regarding the relationship between the warring (ethnic) groups. This is clearly the case with the conflicts in Croatia and Bosnia-Herzegovina. They themselves were an expression of irreconcilable political and national interests in the processes of the collapse of the multi-ethnic Yugoslav Socialist Federation, which led to mass killings, concentration camps, and rape, in short all kinds of (war) crimes, mainly against the civilian population. All this insanity was driven by one strategically "rational" political goal: the ethnic cleansing of undesirable people of different nationality or ethnicity. ${ }^{33}$ The result was the most massive ethnic refugee flows in Europe since World War Two. ${ }^{34}$ Simultaneous with the dissolution of Yugoslavia, new national states were created out of its previous constitutive republics, and the political and economic order was changed (from a one-party socialist to a multi-party capitalist one).

In this chapter, we want to point out that the academic debates and public policies on the return of Serb ${ }^{35}$ refugees to Croatia, both at the national and the international level, have taken insufficient account of all of the new circumstances. According to recent scientific studies and discussions, as well as the results of our research, the circumstances have a largely negative impact on the willingness of a large part of refugees, especially younger, educated, and urban, to return. Here we highlight the socio-demographic, political, economic, cultural, and linguistic changes 
in Croatian society since Croatia declared its independence, and eventually the personal changes that refugees experienced in the process of their involuntary migration, which all, more or less, have affected Serb returnees (including potential ones).

\section{Socio-demographic Changes}

Mass, mostly forced, migration in Croatia in the 1990s occurred in two major flows, primarily in parts of Croatia which were directly affected by military operations. The first refers to the expulsion and exodus of ethnic Croats and other non-Serb ethnic groups from areas in Croatia which, with the help of the Yugoslav army, were conquered by rebel Serbs. The Serb insurrections proclaimed these areas of the Croatian state territory as the Serb Autonomous Region (SAO Krajina). ${ }^{36}$ Later, in connection with the Croatian liberation operations Flash and Storm, ${ }^{37}$ these parts witnessed an exodus of most of their Serb population. Thus, the whole area was in fact emptied of its population, which before the war accounted for approximately 550,000 people in total. The region of eastern Slavonia underwent a somewhat different pattern of migration, but also fell temporarily under the authority of rebel Serbs in Croatia. However, although it was restored to the constitutional and juridical order of Croatia during the process of peaceful reintegration, a large number of Serbs have remained there, and some of them were moved there previously from other Serb regions.

The return of displaced persons (Croats) and refugees (Serbs) was carried out in two main flows. First, displaced persons of Croatian nationality returned, while the basic conditions for the return of ethnic Serbs were provided a little later, in the late 1990s. According to official data of the Croatian government, approximately 109,000 displaced persons returned to the former war zone by the middle of 1998, mainly Croats who had been forced by rebel Serb authorities to flee their homes and areas. This accounted for most of the approximately 127,000 displaced persons registered at the beginning of 1995. However, probably a significant part of that official return was only a formal and not an actual act of returning. The official registration of return included, thus, the process of reconstruction of houses and acquisition of other material rights. Because of that, all members of the household registered as returnees, although in fact only part of the (elderly) household members returned. In our research, we found an even greater disparity between the actual return and the formal registration of Serb returnees. It turned out that just over one third (about 45,000) of officially registered returnees $(133,000)$ actually lived in Croatia at the end of $2010 .^{38}$ 
Croatian population censuses from 2001 and 2011 show the effects of a lasting decrease in the population in those areas in Croatia which had been affected by war. In the six counties from which a relatively major part of the Serbs fled, there was a drastic decline in the total population between the census in 1991 and the census in 2001. ${ }^{39}$ The latter census registered a total population of 246,000 fewer people than had been registered a decade earlier. In the first of the observed decades, the number of people living in this area was reduced by a quarter, and in the next by a further 5 percent. ${ }^{40}$ Taking into account that these counties include areas which were not under the authority of rebel Serbs, and several towns whose population number has remained stable or even increased, ${ }^{41}$ the actual extent of the depopulation of the returnee areas is much higher. This is best exemplified by the Licko-Senjska County, which was completely affected by the war. In the period between 1991 and 2001 it lost 37 percent of its population, and in the next decade this figure rose to more than 40 percent (see Figure 12.1). The loss of population in these areas was far greater in rural areas.

The dramatically reduced number of people who today actually live in the returnee areas in Croatia affects returnees in several ways. First of all, it makes it difficult for them to restore previous social networks and establish new ones. There are no longer, as in the old days, numerous cousins, godparents, friends, and acquaintances on whom returnees can rely to overcome the complex conditions of return. This was confirmed by the respondents in our survey, more than 70 percent of whom indicated that nobody or only a small number of their relatives, pre-war neighbors, and friends had returned to Croatia. ${ }^{43}$ Because of that, these people must feel lonely and isolated, particularly in the small, remote, and scattered villages and hamlets to which a large number of elderly returned. It is undoubtedly an emotional and social loss for them, with practical consequences for everyday life in which people, especially the elderly, should have a mutual help network, not to mention initiatives to improve life in the local community.

As we have already noted, refugee migrations in Croatia have led to a dramatic recomposition in the ethnic structure (including a decline of ethnic Serbs from 12.2 percent to 4.4 percent). In this connection, the decrease in the Serb population is significantly higher in the listed six counties than the average for the whole country. In 1991, 288,000 ethnic Serbs lived in these counties and accounted for 30 percent of their total population, while in 2001 only 65,600 (8.8 percent) were registered (see Figure 12.2). Meanwhile, the immigration of numerous ethnic Croats from Bosnia-Herzegovina, who came to inhabit the places from which Serbs had fled, represents a significant change, especially in some 


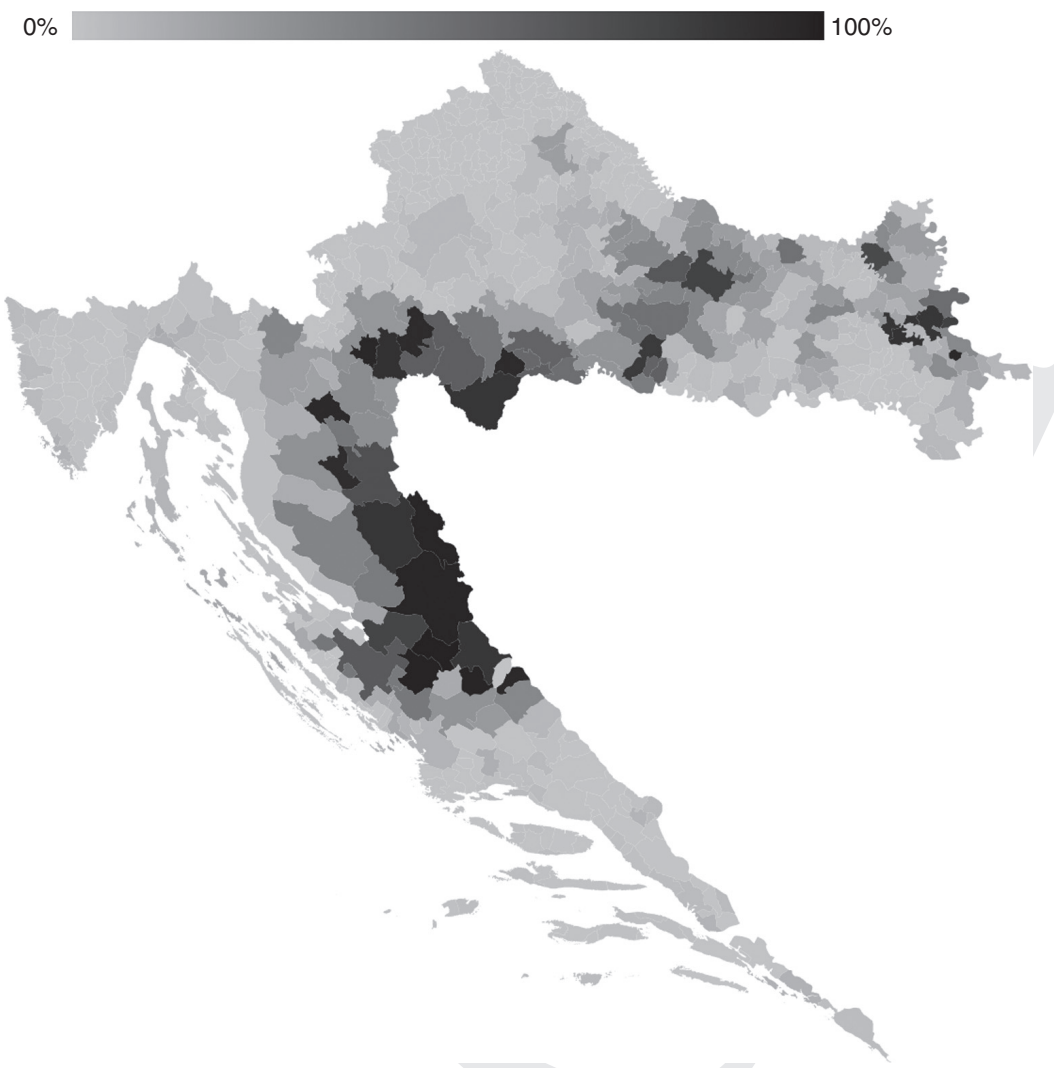

Figure 12.1 Decrease of total number of inhabitants in the percentages on the county level between the 1991 and 2001 population censuses ${ }^{42}$

municipalities and towns. According to the 2001 census, about 61,600 of these immigrants lived in the same counties (on average 8.3 percent, and relatively most of them in Požeška-slavonska County - 13.3 percent) (see Figure 12.3). When Croatian immigrants from Kosovo and some parts of Serbia are added to this number, we get about 10 percent Croatian immigrants, and their concentration is the greatest in towns and municipalities of Serb refugees. In this way not only was the ethnic composition of the population of that area greatly altered, but these settlers brought somewhat different cultural traditions in comparison with those of both domiciled Croats and domiciled Serbs. The research of return to Petrinja has shown that for Serb returnees this represents another adjustment, ${ }^{44}$ as testified by our respondents. 


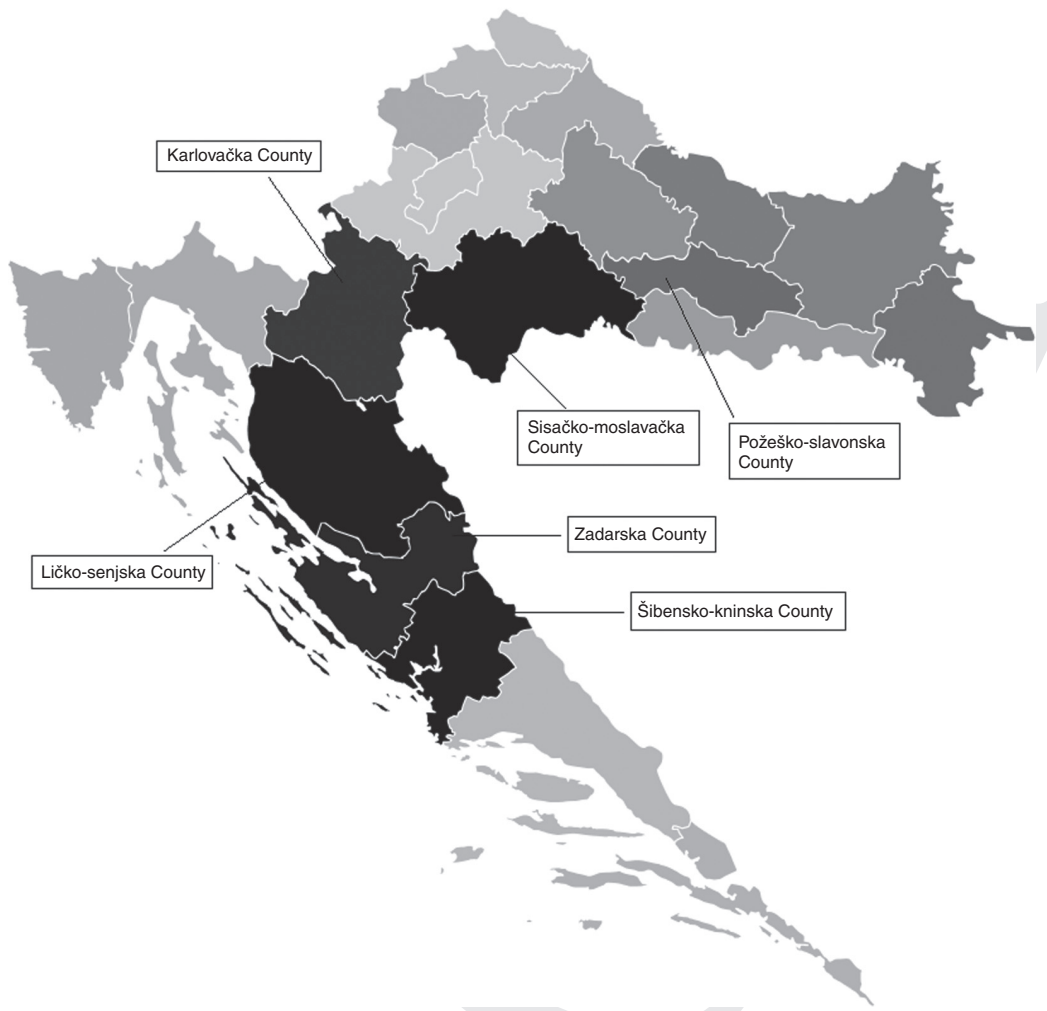

Figure 12.2 Share of ethnic Serbs in total population by municipalities according to the 1991 population census

\section{New Political System}

By all accounts, political changes, which were initiated by the introduction of multi-party elections, affected mostly a large portion of Serb refugees, mostly from rebellious Croatian areas previously populated by an ethnic Serb majority (absolute or relative). The introduction of multiparty elections and the independence of the Republic of Croatia (and later Bosnia-Herzegovina) represented a major obstacle to the movement for Great Serbia aimed at reconstituting Yugoslavia as a unitary or at least predominantly Serb state. A large proportion of the Croatian Serb population in areas where they were an absolute or relative majority were also mobilized for the "Greater Serbia" project, as evidenced by the 


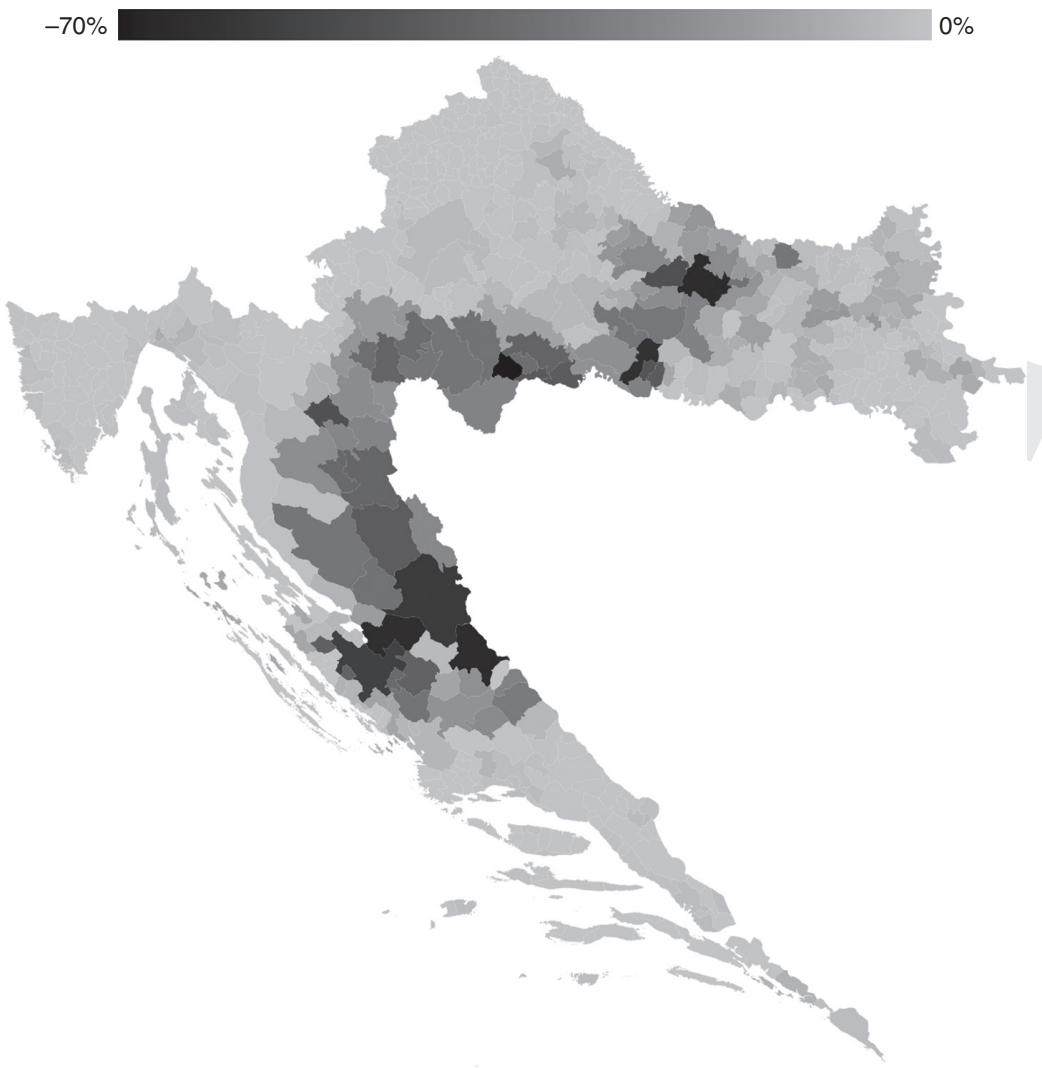

Figure 12.3 Decrease in the percentage of ethnic Serbs on the municipality level between the 1991 and 2001 population censuses

key (irredentist) slogan at mass rallies in these parts: “This is Serbia!" At the same time, Croatian nationalist forces provoked fear and resistance among Serbs in Croatia, led by the winning party in the 1991 democratic elections, the Croatian Democratic Union (Hrvatska demokratska zajednica - HDZ), which in the decade that followed became the undisputed political arbiter in the country.

It seems that a substantial number of Croatian Serbs did not perceive the multi-party democratic elections as a political system of competing for power and its regular shift. They viewed it primarily as the establishment of an anti-Serb regime, i.e., as the actual power of a dominant nationalist Croatian party (HDZ), which won democratic legitimacy, while hardly any other different political party could have won the elections. 
Simultaneously, Milošević's propaganda machine in Belgrade deepened and spread fear among Serbs in Croatia, claiming that the new Croatian state was the successor state of the collaborationist fascist regime in the Independent State of Croatia (Nezavisna Država Hrvatska - NDH), staged during the Second World War and responsible for mass killings of Serbs, Jews, Roma, and Croatian anti-fascists. Distrust of Serbs toward political changes in Croatia was strengthened by the fact that the HDZ government under President Franjo Tudjman used some symbols and terminology which the NDH had also used (from the public administration and administrative units, including the army and police, to the monetary unit), ${ }^{45}$ and was more than tolerant toward extreme right-wing public behavior. Eventually, the revision of historical and other textbooks followed.

In addition, Serbs in Croatia lost their special status of a semiconstitutive people, defined by the Constitution of the Socialist Republic of Croatia as "Serbs in Croatia," and are now equal to other national minorities. They were right in claiming that in the Socialist Republic of Croatia they did not have pure minority status (which was partly true for other minorities too, defined as "nationalities" rather than "national minorities"). It was a special, juridically vague, semi-constitutive yet not fully state-constitutive status. Yet, they were not put on equal footing with Croats in regard to Croatian statehood. Otherwise, socialist Croatia would itself have been federated. In any case, these political changes helped counter-political mobilization of the Croatian Serbs.

However, the special and difficult position of Serbs, especially returnees, stems not so much from the fact that almost two-thirds of their ethnic body left Croatia (permanently), and that they are equal to other ethnic minorities (none of the twenty-two recognized minorities makes up even 1 percent of the total population), but rather from their rebellion and the ethnic and religious conflict with Croats, as the state-constitutive majority. Second, their neighboring kin state openly, and through military means, supported Croatian Serbs' irredentist aspirations. Third, the Croat majority has blamed Serbs in Croatia for hampering Croatian national development in both Yugoslav states (the Kingdom of Yugoslavia and the Socialist Federated Republic of Yugoslavia) and the AustroHungarian Empire. In Croatia and elsewhere in Eastern Europe, minorities are seen as former agents of oppressive imperial policies (imperial minorities), under which the present national majorities suffered and were not able to realize their national states. ${ }^{46}$ For this reason, nationalist rhetoric easily mobilizes anti-minority sentiments among majority peoples. ${ }^{47}$ Finally, the rebel Serbs lost the democratic legitimacy for their demands for autonomy, because of the illiberal and undemocratic way 
in which they went about establishing their self-proclaimed autonomy in the early 1990s, utilizing military force to drive out indigenous Croats. They implemented a brutal policy of ethnic cleansing, intimidation, and deprivation of rights of the local non-Serb population (Croats and others). Furthermore, they suffocated any resistance to such a policy within the Serb community itself, and thus evidently demonstrated internal illiberalism, in fact an anti-democratic orientation. ${ }^{48}$

It seems that a large number of Serbs have not, to this date, made peace with their minority status, although in the meantime the system of protection of their minority political and cultural rights has developed significantly and reached a high standard, at least on a formal level. ${ }^{49}$ Our research indicates that two-thirds of returnee respondents believe that Serbs should not have the status of a national minority but of a constituent people. Slightly less than half ( 42 percent) of them are not satisfied with their political rights (regardless of the extent to which they are really familiar with them), and more than a third (36 percent) say that they feel like second-rate citizens. ${ }^{50}$ We can, with high probability, assume that negative attitudes about the position of Serbs in Croatia today are even more pronounced among Serb refugees who do not wish to return to Croatia. The very act of returning represents in a certain way a symbolic acknowledgement of the defeat of the Greater Serbian project, which was actively or passively supported by a substantial proportion of Serbs in Croatia.

Security and political conditions for minority return have gradually started to improve since the first left-center coalition came to power in 2000. Such a policy was continued by the new government of the reformed HDZ at the end of 2003, which, moreover, included the Independent Democratic Serb Party (Samostalna demokratska srpska stranka - SDSS) as political representatives of Serbs in Croatia in the coalition governement. However, the potential for Serb return was mainly exhausted by then, it seems.

Changes in the political regime were accompanied by the reorganization of the institutional structure of public administration and public services. Perhaps the most important novelty for (potential) returnees concerns local and regional self-government. Considering only six counties (districts) with high portions of Serb population before the war, the number of cities and municipalities increased, specifically, from about 30 to 117 . This means that today the majority of the population actually lives in local government units that had not existed as such before 1991. Renaming some settlements as well as certain administrative units should also be taken into consideration here. In 1993, regional selfgovernment, consisting of twenty counties (districts), was introduced 
into the administrative system of the Republic of Croatia, which was a new level of power not known in Socialist Yugoslavia. In addition to the system of local and regional self-governments, other institutions of public administration experienced major or minor changes, both in their names and in the distribution of authority and responsibility. For the purposes of our discussion, it is important to emphasize that for Serb returnees this resulted in their "institutional illiteracy," that is a sense of "foreignness" in a once familiar institutional environment, which makes the already burdensome post-return adjustment even more difficult for them.

\section{New Economic System}

In its economic sphere Croatia has experienced a transformation from a (self-managed) socialist system to a capitalist market economy. Job security used to be practically guaranteed, i.e., it was hardly possible for a worker or an employee to be fired even when he or she violated labor rules. Nowadays working people find themselves overnight "on the street" due to the collapse and/or privatization of state companies. These firms in the best-case scenario end up being "restructured" (read: a large proportion of employees are made "redundant"), and in the worst-case scenario (for the workers) end up in bankruptcy. While "self-managers" were involved in the management of "their" companies (through workers' councils), and were encouraged by the socialist system to consider themselves equal with the management regarding the disposal of the company's assets and resources, now they are (again) reduced to mere "wage laborers" whose efficiency is being determined solely by the management. The workers are "accountable" to company owners, i.e., shareholders. Social (state) companies no longer provide flats for their employees, but banks (now mostly foreign-owned) offer housing and other loans, and spur consumer aspirations through which they trick masses of people, who are not used to the relentless money market, into "debt bondage." Even though Serb refugees were able to see similar, although somewhat slower, changes in the countries where they sought refuge (mainly Serbia and Bosnia-Herzegovina), these further reinforce the impression of "foreignness" of the context of return.

For almost five years the areas from which the majority of Serbs had escaped were politically unrecognized and economically isolated from the rest of Croatia and the world, which only accelerated the decline of manufacturing, trading, and handicrafts companies that had operated there until the outbreak of the conflict. Firms in the war zones which remained under the control of Croatian authorities faced a similar fate. 
Thus, by the end of the war, numerous jobs which had provided employment opportunities for the local population had been abolished.

Upon inclusion of these areas in the constitutional and legal order of the Republic of Croatia, indeed some new but still few jobs were created in new private (or privatized) companies. As a rare positive example, we should emphasize that some Serb returnees succeeded in developing and modernizing their farms. ${ }^{51}$ "Old" jobs were kept mainly in state and local government (police and administration), and public services (education, health) and state-owned companies (railways, postal services). In addition to a generally low job supply, we might suspect that the remaining ethnic Serbs in Croatia and even more so Serb returnees could not get a job on equal terms with Croat job-seekers. Furthermore, the terminology and the symbolic meaning of public institutions have changed. Thus, the active workplace environment also became "foreign" to Serb returnees. This is why labor-market inactive returnees returned more easily to the villages. Relying on their pensions and the help of other family members who remained in the country of refuge or who moved to a third country (refugee transnational survival strategy), and small-scale agriculture on their land, they can survive in the harsh conditions of the return. ${ }^{52}$

\section{Cultural, Linguistic, and Symbolic Changes}

The period following the declaration of Croatian independence is also associated with significant changes in political symbols and cultural iconography. A stronger emphasis was placed on symbols that were present even before, such as the shield-shaped red and white checkerboard, or the anthem Lijepa Naša. At the same time the iconography, which had been repressed until then, entered the public space, for example the Croatian wattle. School textbooks and the media (re)affirmed certain prominent figures and events in Croatian history, thus constructing a new cultural tradition which is usually accompanied by profound political shifts in a country. Croatian kings, dukes and bans, and great national figures (such as Ante Starčevic), in new conjuction with local Christian saints and church officials, took up the public scene, while Partisan figures and anti-fascist iconography disappeared from it. Even the (previously cherished) Croatian Peasants' Revolt against the tyranny of the foreign feudalist (Franjo Tahy) hardly fits any more into this retraditionalization of the Croatian national state. Something similar can be found in literature and art, in which some authors and artists lost their dominant role in the public sphere, while others took their place.

National cultural "purists" have, in particular, made sure to "cleanse" the language, resorting to forgotten archaic Croatian expressions, 
artificially coined words used in the NDH, and newly coined words, in order to expel "foreign words," but also to free the standard Croatian (official) language from any admixture of the Serbian language. This cultural project of "exercising discipline" over language could not avoid caricature exaggeration, which has been mocked by the liberal cultural public, while more importantly a great portion of the "new-oldCroatian expressions" are simply not accepted in the language practices of Croatian language speakers.

Although partially successful, the language "reform" affected Serb returnees, who have become linguistically distinctive or incompetent in the renewed Croatian language. Serbs in Croatia considered standard Croatian, justifiably, their language (which was then called Croato-Serb, i.e., the Serbo-Croatian language). The creators of modern languages in the Illyrian national movement, which aimed to have one standard language for Croats and Serbs in Austro-Hungary, took the Ijekavian Štokavian dialect, spoken by a part of Croats and Serbs, not only in Croatia but also in Bosnia-Herzegovina, as the standard variant of the language. Ethnic Serb writers in Croatia used standard Croatian in their writing. However, even then, many Croats used regional dialects in their spoken language, as they do today, but Serbs in Croatia did not, especially in the area of Banovina. Anyway, this language was different from the Štokavian Ekavian language standard in Serbia, which was and has remained Serbian..$^{53}$

Serbs in Croatia traditionally have not used Serbian language standards, now exclusively called Serbian. Thus, they now find themselves facing the decision as to whether to be acknowledged as speakers of the Croatian or of the Serbian language. In the first case - not being a language community - there is no reason for them to have their own schools, taught in Serbian. In the second - adopting Serbian language standards - they make themselves a linguistically "visible" minority. Interestingly enough, only about a quarter of the existing Serb population in Croatia (at the time of the 1991 census) selected the second option (some 50,000 people, making up 1.01 percent of the population). A negligible margin (at the same time) tried to pretend that a hyphenated language option still exists, i.e., by choosing the variants Serbo-Croatian (0.11 percent) or Croato-Serb (0.05 percent of the population) ${ }^{54}$ While living for years in exile, mostly in Serbia and the Republic of Serbska (Republika Srpska), Serb refugees from Croatia had to adapt to the Serbian Ekavian standard, which after their return only increased and emphasized their linguistic distinctiveness. In short, due to the language policy of the new Croatian government as well as new language habits acquired during exile, Croatian Serbs have become a visible language minority, which was not the case before the conflict. 


\section{Conclusion}

Recent critical literature as well as our own research has challenged the traditional notion of refugee return, in particular minority refugee return. It has been confirmed that in a post-conflict society, return is not a single act, and it does not help minority refugees to reintegrate into the home and homeland they had to leave. Therefore, it is not surprising that a large proportion of refugees (primarily young, educated, urban people with children) do not opt for return as a durable solution, regardless of whether, in the country of their origin, physical and political security as well as fundamental human and returnee rights have been established. By approaching the issue strategically and rationally, minority refugees become aware of thorough transformations in the country of their origin and in the immediate vicinity of their homes. Scientists have begun discovering that, and we hope that international creators of refugee and returnee policies will start acknowledging it as well.

In this chapter we have tried to identify some key political, economic, socio-demographic, cultural, and symbolic changes in the case of Republic of Croatia, which more or less affect the lives of Serb minority returnees and the (un)willingness of many Serb refugees to return. Finally, one should not forget that in the years they spent in exile, refugees themselves underwent changes on a personal, family, and social level. Although most of them fled to Serbia and the Republic of Serbska, many were not accepted with open arms and welcomed as they had expected, and they had to adapt to new environments, which were for them "foreign" even though they belonged to the same nation. It can be assumed that many refugees (returnees) have experienced changes in their own lives, family situations, and eventually life aspirations. This particularly applies to younger generations and those who left small, rural, and remote settlements. Most of them migrated from small rural villages to larger and urban settlements. ${ }^{55}$ This change has certainly influenced the expectations and aspirations of people in terms of infrastructure standards, the availability of cultural and entertainment facilities, housing quality, and professional opportunities. Such persons can now, from a different perspective, evaluate their pre-war settlement and the area they left, which do not even provide opportunities for the life that existed before the war, let alone offer attractive prospects for development.

The same changes furthermore account for the negative selection of returnees in terms of their age, economic activity, education, lifestyle, and housing. The decision to return by elderly, rural, economically inactive minority refugees in retirement, with some land to farm mainly for their own needs, is as rational as is the decision of many young, educated, 
urban minority refugees with children (integrated in the new environment) to remain in the country where they took refuge, or in a third country. Actually, the decision is often made at the level of the (wider) family, and includes a transnational family strategy, with a division of roles. In this division, the elderly return to rebuild homes and farms, and keep them for their children and grandchildren, while the younger, if they can, provide financial support for their parents and grandparents who have returned, and occasionally visit the rebuilt refugee homes for family gatherings. In this way, they ensure the option of their "return" over the long term, when favorable conditions are met. In any case, restitution of land, houses, and flats remains an important material capital, which can be used for future life options by the inheritors. In short, we have tried to suggest that minority (Serb) refugee return to a post-conflict society (such as Croatian) can actually be better understood and explained as a practically new immigration, instead of simply as reintegration into the society of origin.

\section{Notes}

1 Mircea Eliade, Sveto i profano (Zagreb: AGM, 2002).

2 Oscar Handlin, The Uprooted: The Epic Story of the Great Migrations That Made the American People (Philadelphia: University of Pennsylvania Press, 2002); Liisa Malkki, "National Geographic: The Rooting of Peoples and the Territorialization of National Identity Among Scholars and Refugees," in Cultural Anthropology, Vol. 7, No. 1 (February 1992), pp. 23-44.

3 George Gmelch, "Return Migration," in Annual Review of Anthropology, Issue 9 (October 1980), p. 135.

4 E. I. MacDonald, Living the Experience: Migration, Exclusion and Anti-Racist Practice (Halifax: Fernewood Publishing Press, 2006), p. 86.

5 Tim Allen and Hubert Morsink, When Refugees Go Home: African Experiences (Geneva and Oxford: UNRISD; James Currey Ltd; Africa World Press, Inc., 1994).

6 Liisa H. Malkki, Purity and Exile: Violence, Memory, and National Cosmology Among Hutu Refugees in Tanzania (University of Chicago Press, 1995).

7 Anneke Rachel Smit, "Housing and Property Restitution and IDP Return in Kosovo," in International Migration, Vol. 44, No. 3 (August 2006), pp. 63-64.

8 Malkki, "National Geographic," p. 31.

9 Laura Hammond, "Examining the Discourse of Repatriation: Towards a More Proactive Theory of Return Migration," in R. Black and K. Koser (eds.), The End of the Refugee Cycle (Oxford: Berghahn, 1999), p. 227.

10 Richard Black and Saskia Gent, "Sustainable Return in Post-Conflict Contexts," in International Migration, Vol. 44, No. 3 (August 2006): p. 19.

11 The term minority returnees, as it was well noticed by Joanna Harvey ("Return Dynamics in Bosnia and Croatia: A Comparative Analysis" in International Migration, Vol. 44, No. 3 (August 2006), pp. 89-144.) in the 
reports on refugee movements in this region, is not used in its common meaning of national minority, but it relates to the groups that return on the territory under the effective control of another ethnic grouup (even if the returnees locally account for the majority of population).

12 Anders H. Stefansson, "Homes in the Making: Property Restitution, Refugee Return, and Senses of Belonging in a Post-War Bosnian Town," in International Migration, Vol. 44, No. 3 (August 2006), p. 120.

13 Barbara E. Harrell-Bond, "Repatriation: Under What Conditions Is It the Most Desirable Solution for Refugees? An Agenda for Research," in African Studies Review, Vol. 32, No. 1 (April 1989), pp. 41-69.

14 B. S. Chimni, "Refugees, Return and Reconstruction of 'Post-Conflict' Societies: A Critical Perspective," in International Peacekeeping, Vol. 9, No. 2 (Summer 2002), pp. 163-180.

$15 \mathrm{Brad}$ K. Blitz, "New Beginnings? Refugee Returns and Post-Conflict Integration in the Former Yugoslavia," in War and Change in the Balkans, Nationalism, Conflict and Cooperation (Cambridge: Cambridge University Press, 2006), p. 242.

16 This chapter is based in part on a research project on the return of Serb refugees to Croatia, which the authors conducted at the end of 2010 for UNHCR in Croatia, and whose integral report was published as a book, both in Croatian and English. Here, we refer to the English version of the book: Minority Return in Croatia - Study of an Open Process. Along with the representative survey of Serb (minority) returnees, on a sample of 1,402 respondents in all returnee areas we conducted in-depth interviews with more than 80 returnees of various socio-demographic profiles and returnee experiences. The qualitative study helped us in constructing different typologies of returnees.

17 Terence Ranger, "Studying Repatriation as Part of African Social History," in Allen, T. and Morsink, H. (eds.), When Refugees Go Home. African Experiences (Geneva and Oxford: UNRISD; James Currey Ltd; Africa World Press, Inc., 1994), pp. 279-294.

18 Stef Jansen and Staffan Löfving, "Introduction: Movement, Violence, and the Making of Home," in Focaal - Fournal of Global and Historical Anthropology, Vol. 2007, No. 49 (2007), pp. 3-14.

19 Marita Eastmond, "Introduction: Reconciliation, Reconstruction, and Everyday Life in War-Torn Societies," in Focaal - Fournal of Global and Historical Anthropology, Vol. 2010, No. 57 (July 2010), p. 9.

20 Ruerd Ruben, Marieke Van Houte, and Tine Davids, "What Determines the Embeddedness of Forced-Return Migrants? Rethinking the Role of Pre- and Post-Return Assistance," in International Migration Review, Vol. 43, No. 4 (Winter 2009), p. 932.

21 Akhil Gupta and James Ferguson, "Beyond 'Culture': Space, Identity and Politics of Difference," in A. Gupta and J. Ferguson (eds.), Culture, Power, Place: Explorations in Critical Anthropology (Durham, NC: Duke University Press, 1997), pp. 33-51; and Malkki, Purity and Exile.

22 Daniela Heimerl, "The Return of Refugees and Internally Displaced Persons: From Coercion to Sustainability?," in International Peacekeeping, Vol. 12, No. 3 (Autumn 2005), p. 380. 
23 Jasna Čapo Žmegač, "Različiti pristupi povratnim migracijama: primjer Hrvatske," in Studia ethnologica Croatica, Vol. 22, No. 1 (December 2010), pp. 14,31 .

24 Marita Eastmond, "Transnational Returns and Reconstruction in PostWar Bosnia-Herzegovina," in International Migration, Vol. 44, No. 3 (August 2006), pp. 141-166; Ruben, Van Houte, and Davids, "What Determines the Embeddedness of Forced-Return Migrants?,” p. 911.

25 Eastmond, "Transnational Returns and Reconstruction in Post-War BosniaHerzegovina," pp. 142-143.

26 Ibid., p. 143.

27 Stefansson, "Homes in the Making," p. 125.

28 Tania Ghanem, When Forced Migrants Return'home': The Psychosocial Difficulties Returnees Encounter in the Reintegration Process, RSC Working Paper ; No. 16 (University of Oxford. Refugee Studies Centre, 2003), p. 21.

29 Helen Muggeridge and Giorgia Doná, "Back Home? Refugees' Experiences of Their First Visit back to Their Country of Origin," in Fournal of Refugee Studies, Vol. 19, No. 4 (December 2006), p. 415.

30 Marieke van Houte and Tine Davids, "Development and Return Migration: From Policy Panacea to Migrant Perspective Sustainability," in Third World Quarterly, Vol. 29, No. 7 (October 2008), p. 1412.

31 Megan Bradley, "Back to Basics: The Conditions of Just Refugee Returns," in Fournal of Refugee Studies, Vol. 21, No. 3 (September 2008), p. 158.

32 van Houte and Davids, "Development and Return Migration," p. 1425.

33 Although we do not grant amnesty to any of the parties in the multi-ethnic conflicts, we also do not think that they are equally responsible for war victims and involuntary migrants (displaced persons and refugees). This is confirmed by scientific studies, the processes in The Hague and the testimonies of surviving victims.

34 War and ethnic conflicts and hostilities in the period 1991-1997 caused displacement of about 950,000 Croatian inhabitants (out of about 4.5 million total population). According to Mikić (Ljubomir Mikić, "Republika Hrvatska: Izbjegli i raseljeni bivši nositelji stanarskih prava - Osvrt na psistup stečenim pravima i stambeno zbrinjavanje manjinskih povratnika u 2008." Koalicija za promociju i zaštitu ljudskih prava, 2008, p. 2), there were about 550,000 Croatian citizens of mostly Croatian nationality and some 400,000 of Serb nationality among the displacees in that period. These are probably high estimates for both one and the other group, and they probably include multiple displacements. Recent data recollected by the UNHCR in late 2010 indicates 550,000 displaced persons in Croatia for the period 1991/1992, and 250,000 Serb refugees from Croatia after 1995. In addition, one ought to bear in mind some 400,000 refugees from Bosnia-Herzegovina who sought refuge in Croatia in 1991/1992. There are other estimates as well, and we do not insist on the ones presented here.

35 We propose to differentiate the broader term Serbs (Croatian: Srbi) that relates to all ethnic Serbs on the territories of the former Socialist Federative Republic of Yugoslavia (SFRY) and elsewhere in the world from the term Serbians (Croatian: Srbijanci), which only relates to Serbs (originating from) Serbia. The same applies to adjectives, for instance "Serb refugees" (from 
Croatia) in the sense of other refugees of Serb nationality from Serbian refugees, which can only apply to Serb refugees from Serbia. Long time ago, Serbs in Croatia (that is all Serbs outside of Serbia) were referred to as "Serbs from the other side" (Croatian: prečanski Srbi) in order to differentiate them from the Serbians in Serbia.

36 In spring 1992 UN forces, or more precisely UNPROFOR was deployed in the occupied areas and areas of armed aconflict designated as United Nations Protected Areas (UNPAs). There were four UNPA sectors: North, South, West and East. In this paper we mainly focus on demographic changes in former UNPA sectors North, South and West which coverned significant part of six counties: Požeško-slavonska, Sisačko-moslavačka, Karlovačka, Ličko-sanjska, Šibensko-kninska and Zadarska. See picture number 1.

37 Operation Flash was conducted in May 1995 in the area of UNPA Sector West, and operation Storm was conducted in August 1995 in the area of UNPA Sector North and South.

38 Mesić and Bagić, Minority Return to Croatia-Study of an Open Process, p. 77.

39 The data refer to six above listed counties which were partially or completely part of UNPA sectors South, North and West, i.e. affected by operations Flash and Storm.

40 The impact of war on the decrease in the number of domiciled population is even greater, because after 1995 the depopulated areas were settled by a substantial number of ethnic Croats from Bosnia-Herzegovina and Kosovo. According to the data from the 2011 census around 115,000 people (16.2 percent) in these counties came from abroad.

41 e.g. Zadar, Šibenik, Sisak and Požega.

42 The authors calculated figures based on the census demographic data, and maps were then designed by the Science and Society Sinergy Institute. Units on the maps represent division of the state territory in 2011.

43 Mesić and Bagić, Minority Return to Croatia-Study of an Open Process, p. 128.

44 Snježana Gregurović, "Relacijska dimenzija etnickog identiteta: istraživanje etničkih kategorija na primjeru Petrinje," in Migracijske $i$ etnicke teme Vol. 21, No. 3 (September 2005), pp. 221-242.

45 Some of these symbols are traditional Croatian medieval symbols and terms, but in the minds of a significant number of Croatian Serbs they are associated only with the NDH.

46 Boris Tsilevich, "New Democracies in the Old World: Remarks on Will Kymlicka's Approach to Nation-Building in Post-Communist Europe," in Will Kymlicka and Magda Opalski (eds.), Can Liberal Pluralism Be Exported (Oxford University Press, 2001), p. 161.

47 One extreme example of such negative sentiments and prejudices toward (some) minorities is the decision of a district court in Croatia. In an extended explanation for its sentence imposed on a Serb returnee charged with war crime during the recent civil war in Croatia, the court included accusation for the century-old oppression over Croats. It had been, namely, exercised or backed by the defendant's ancestors (who had come in Croatia with Turks 500 years ago) ("Sat povijesti na sudu u Gospicu", Globus, October 3, 2003). 
48 Mesić, "Minorities in Croatia and Challenges of Multiculturalism," pp. 286-287.

49 Milan Mesić, "Europski standardi manjinske zaštite i položaj manjina u Hrvatskoj," in Revija za sociologiju, Vol. 34, No. 3-4 (December 2003).

50 Milan Mesić and Dragan Bagić, Minority Return to Croatia-Study of an Open Process (Zagreb: UNHCR, 2011), pp. 133-135.

51 Whose stories are presented in our book as illustrations of successful return. See: Mesić and Bagić, Minority Return to Croatia - Study of an Open Process.

52 Mesić and Bagić, Minority Return to Croatia-Study of an Open Process, pp. 101-109.

53 See more in: Ranko Bugarski, "Language, Identity and Borders in the Former Serbo-Croatian Area," in Fournal of Multilingual and Multicultural Development, Vol. 33, No. 3 (March 2012), pp. 219-235; Ivan Šiber, "War and the Changes in Social Distance toward the Ethnic Minorities in Croatia," in Politicka Misao, Vol. 34, No. 5 (February 1998), pp. 3-26.

54 Mesić, "Minorities in Croatia and Challenges of Multiculturalism," p. 276.

55 Marija Brajdić Vuković and Dragan Bagić, Motivational and Emotional Factors for the Return of Refugees to Their Homes and the Acceptance of Their Return by the Local Population - Empirical Research (Zagreb: OSCE Mission to Croatia, 2004). 